\title{
エポキシシラン転位の発見とその合成反応への展開
}

\author{
佐々木道子
}

\section{Development and Synthetic Application of Epoxysilane Rearrangement}

\author{
Michiko SASAKI \\ Graduate School of Medical Sciences, Hiroshima University, 1-2-3 Kasumi, \\ Minami-Ku, Hiroshima 734-8553, Japan
}

(Received March 31, 2008)

\begin{abstract}
$O$-Silyl cyanohydrins of $\beta$-silyl- $\alpha, \beta$-epoxyaldehyde can function as a highly functionalized homoenolate equivalent via a tandem sequence involving base-promoted ring opening, Brook rearrangement, and alkylation at the allylic position. We named this rearrangement epoxysilane rearrangement. Based on results of mechanistic studies involving competitive experiments using diastereomeric cyanohydrins, we propose a reaction pathway involving a silicate intermediate formed by a concerted process via an anti-opening of the epoxide followed by the formation of an O-Si bond. Moreover, results of mechanistic studies on the rearrangement led to a conceptually novel approach to the chirality transfer in which epoxide chirality can be transferred into carbanion. We demonstrate the usefulness of the rearrangement through application to the following reactions: (1) reaction of $\gamma$ - $p$-toluenesulfonyl- $\alpha$, $\beta$-epoxysilane with alkyl halides and aldehydes followed by treatment with $n$ - $\mathrm{Bu}_{4} \mathrm{NF}$, which affords $\alpha, \beta$-unsaturated aldehydes (2) reaction of $\gamma$-phosphonio- $\alpha, \beta$ -epoxysilane with aldehydes, which affords dienol silyl ether derivatives (3) reaction of an enoate bearing an eposysilane moiety at the $\alpha$-position with lithium enolate of 2 -chloroacetamide, which affords highly functionalized cyclopropane derivatives.
\end{abstract}

Key words_-Brook rearrangement; tandem reactions; epoxide; chirality transfer

\section{1. はじめに}

光学活性エポキシドは, Sharpless 法, ${ }^{1)}$ Shi 法2)な ごを用いれば，極めて容易に入手可能であることか ら，有機合成における最も重要な不斉合成素子の 1 つとなつているが，そのキラリティは開環反応を経 てキラルな酸素官能基の導入に用いられるのが一般 的である。われわれは，エポキシシラン転位と名付 けた反応を開発し，これによって，エポキシドのキ ラリティをカルバニオンに転写することに成功し た。本稿では，エポキシシラン転位の開発とその不 斉反応を含む合成反応への展開について述べる.

\section{2.エポキシシラン転位の発見 ${ }^{3}$}

われわれのグループでは数年来，Brook 転位（シ リル基の炭素原子から酸素原子への 1,2-ア二オ二 ツク転位) ${ }^{4-12)}$ を利用する新規合成反応の開発に取

広島大学大学院医歯薬学総合研究科（干734-8553 広島 市南区霞 1-2-3)

e-mail: misasaki@hiroshima-u.ac.jp

本総説は, 平成 19 年度日本薬学会中国四国支部奨励賞 の受賞を記念して記述したものである.
り組んできたが, 13-15) この過程で Brook 転位を利用 すればエポキシドのキラリティをカルバニオンに転 写できるのではないかという着想を持った。すなわ ち, 光学活性な $\alpha, \beta$-エポキシシランの $\gamma$-位にアニ オンを発生させれば, 1 においてエポキシドの開環／ Brook 転位が連続的に起こって, キラルカルバニオ ン 4, $\mathbf{4}^{\prime}$ が生成し，これを種々の求電子剂で捕捉で きるのではないかというものである (Scheme 1).

$\alpha, \beta$-エポキシシランの $\gamma$ 位にカルバニオンを発生 させる方法として，電子求引性基を隣接位に有する エポキシシランの塩基による脱プロトン化を用いる ことにした，対応する基質として，合成化学的な柔

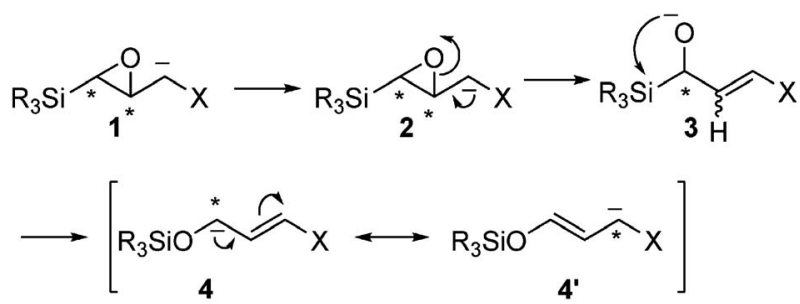

Scheme 1. 
軟性を考慮し，O-シリルシアノヒドリン誘導体 $\mathbf{5}$ に着目した．ラセミ体の $\mathbf{5}$ はプロパルギルアルコー ルから容易に導かれるエポキシアルデヒドに対し TBSCN を作用させることによりジアステレオマー の混合物として得られ，相対配置は $\mathbf{5 b}$ の $\mathrm{X}$ 線結晶 解析により決定した。

$\mathbf{5 a}, \mathbf{b}$ とヨウ化メチルの $\mathrm{THF}$ 溶液に $-80^{\circ} \mathrm{C}$ で LDA を加え，同温で 5 分間反応させたところ，脱 プロトン化／エポキシドの開環／Brook 転位が起こ つたのちにアリル位でメチル化された $6(\mathrm{R}=\mathrm{Me})$ がそれぞれ $82 \%$ と $84 \%$ の収率で得られた（Table 1)。ほかのアルキル化剤を用いても同様に反応が進 行した.

この反応において注目すべき点は，2つのジアス テレオマー間で 6 の $E / Z$ 比が著しく異なることで ある。この結果は，ケテンイミネート 7 のような共 通の中間体を主経路に含まず，脱プロトン化とエポ キシドの開環が協奏的に進行していることを示唆し ている (Fig. 1)。さらに，6 以外のアルキル化体が 全く検出されないという結果は，その後の過程も協 奏的に進行している可能性が高いことを示してい る。そこで，本反応が不斉転写反応に展開可能なの ではないかと考え，まず，詳細な反応機構を明らか にすることにした，以下にその概略を示す。

\section{3. エポキシシラン転位の反応機構16)}

まず，同一溶媒を用いて対カチオン及び塩基の種 類と $E / Z$ 比との関係を調べたが，有意な相関はみ
られなかつた。そこで溶媒の極性との関係を検討し たところ，へキサン，トルエンのような低極性溶媒 中で，明らかに Z-体の生成比が増大した。これ は，例えば（Z)-8'のような分子内キレーション構 造が有利になった結果と考えれば説明することがで きる (Scheme 2)，このことは，HMPA を添加す ると $Z$-選択性が低下するという結果からも支持さ れる.

この仮定に基づけば， $(Z)-\mathbf{8}$ と（E)-8 の間に平 衡が存在することになるが，この平衡が，アルキル 化剂と反応する前に達成されていれば，ジアステレ オマー 5a, b 間での $E / Z$ 比に違いがなくなるの で，実験結果と矛盾する。溶媒効果とジアステレオ マー間の $E / Z$ 比の違いを合理的に説明するために は以下の条件を満たす必要がある。1）この反応は
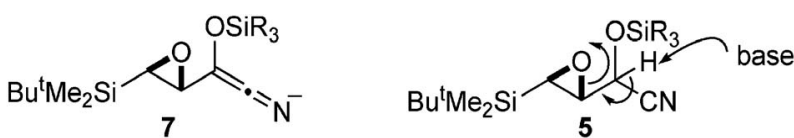

Fig. 1. Base-promoted Ring-opening of $O$-Silyl Cyanohydrins of $\beta$-Silyl- $\alpha, \beta$-epoxyaldehyde<smiles>[R19]OC=CC(C#N)O[Na]</smiles>

$(E)-8$<smiles>[R3]O/C=C\C(C#N)O[R5]</smiles>

$(Z)-8$

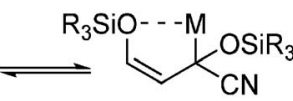

$(Z)-8^{\prime}$
Scheme 2 .

Table 1. Tandem Base-promoted Ring-opening/Brook Rearrangement/Allylic Alkylation of $O$-Silyl Cyanohydrins of $\beta$-Silyl- $\alpha, \beta$-epoxyaldehyde

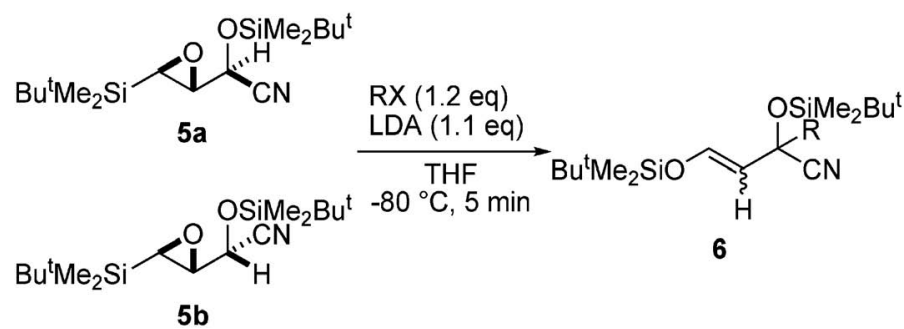

\begin{tabular}{lcccccc}
\hline \hline \multirow{2}{*}{$\mathrm{RX}$} & \multicolumn{2}{c}{ From 5a } & & \multicolumn{2}{c}{ From 5b } \\
\cline { 2 - 3 } \cline { 6 - 7 } & Yield (\%) & $E: Z$ & & Yield (\%) & $E: Z$ \\
\hline Mel & 82 & $2.5: 1$ & & 84 & $22.0: 1$ \\
Etl & 76 & $2.9: 1$ & & 74 & $28.0: 1$ \\
$i-\mathrm{Prl}$ & 58 & $2.8: 1$ & & 74 & $31.0: 1$ \\
$\mathrm{PhCH}_{2} \mathrm{Br}$ & 86 & $2.7: 1$ & & 98 & $47.0: 1$ \\
$\mathrm{CH}_{2}=\mathrm{CHCH}_{2} \mathrm{Br}$ & 83 & $3.4: 1$ & & 87 & $40.0: 1$ \\
\hline
\end{tabular}


8 以外の中間体を経由して進行し, 複数の異性体か らなるその中間体の生成比が原料の立体配置及び溶 媒の極性に依存する，2）一方の異性体からは（E)6が，また他方からは $(Z)-6$ が優先的に生成する.

3）中間体から 6 が生成する過程において 8 を経由 する可能性があるが，その場合 $E / Z$ 間の異性化は 起こらない．以上を満たす反応機構として Scheme 3 に示すような経路を考えた。すなわち，協奏的な 脱プロトン化／エポキシドの開環反応によって生成 したオキシドイオンがケイ素原子と結合を作ること により，五配位のシリケート中間体（E)-9 と（Z)9 が形成され，その後，協奏的に C4-Si 結合の切断／ アリル転位が起こるというものである。 シリケート (E) -9 は，5a の syn 脱離若しくは，5b の anti 脱離 により形成され，（Z）-9 は，5a の anti 脱離若しく は, $5 \mathbf{b}$ の syn 脱離を経て形成される。その後, 協 奏的に C4-Si の切断／アリル転位が起こるためには, C4-Si 結合と二重結合の $\pi$ 軌道が平行に並ぶ必要が あるため，C3-C4 結合が回転し， $(E)$-9 はコンフォ メーション $(E)-9 \mathrm{a}, \mathrm{b}$ を， $(Z)-9$ はコンフォメーシ ヨン $(Z)-9 a, b$ を取る。 そして, $(E)-9 a$ と $(Z)$ 9aからは $(Z)-6$ が, $(E)-9 b$ と $(Z)-9 b$ からは $(E)$ 6 が生成する。（E) -9a, b, (Z) -9a, b のうち，（Z)9aについてのみ，金属イオンとのキレーションが 可能である。もし，このキレーションが $Z$-体生成
に係わっているのであれば, $(Z)-9$ からの方が $(E)$ 9 からよりも Z-体の生成比が高くなるはずである. 5b と比較して 5a からの方が Z-体の生成比が高い ことから，もしこの機構が正しければ，エポキシド の開環は除去されるプロトンと切断される炭素-酸 素結合が逆方向に配置したコンフォメーションを経 る，いわゆる anti脱離で進行しているはずである.

$\mathbf{5 a}, \mathbf{b}$ の開環反応が ant $i$ 脱離で進行しているのか, syn 脱離で進行しているのかを特定するため, ジア ステレオマー間での競合実験を行うことにした。 $s y n$ 脱離で進行している場合, 5a からの遷移状態で は 4 位のプロトンと同じ側にあるのがニトリル基 (A value $=0.2)$ であるのに対し，5b からの遷移状 態では立体反発の大きい OTBS 基（OTMS 基の A value=0.74）である（Fig. 2)．したがって，5a の 方が5bよりも反応性が高いと考えられる。逆に anti 脱離の場合は $\mathbf{5 b}$ の方が，反応性が高くなる。

そこで， $\mathbf{5 a}: \mathbf{5 b}$ の混合物 $(1.0: 1.0)$ に 0.5 当量 のヨウ化メチルの存在下, 0.5 当量の LDA を加 え, $-80^{\circ} \mathrm{C}$ で 5 分間反応させたところ， $35 \%$ のメ チル化体 $6(\mathrm{R}=\mathrm{Me})$ とともに，5 が 40\%の収率で 回収され，その比は 5a: 5b=1.00:0.70であった (Table 2)，この結果は 5b の方が反応性が高いとい うことを示しており, anti 脱離で進行していること を示唆している，さらに，金属とのキレーションを
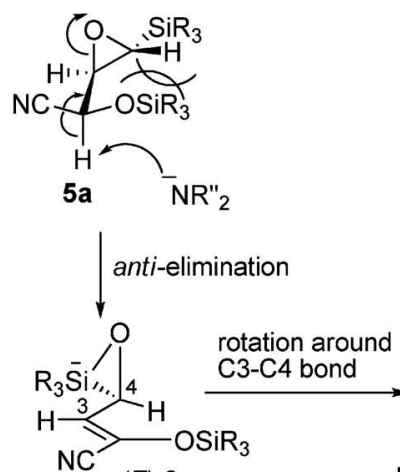

$(Z)-9$ syn-elimination

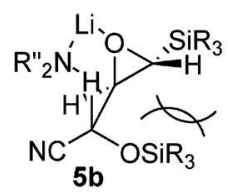
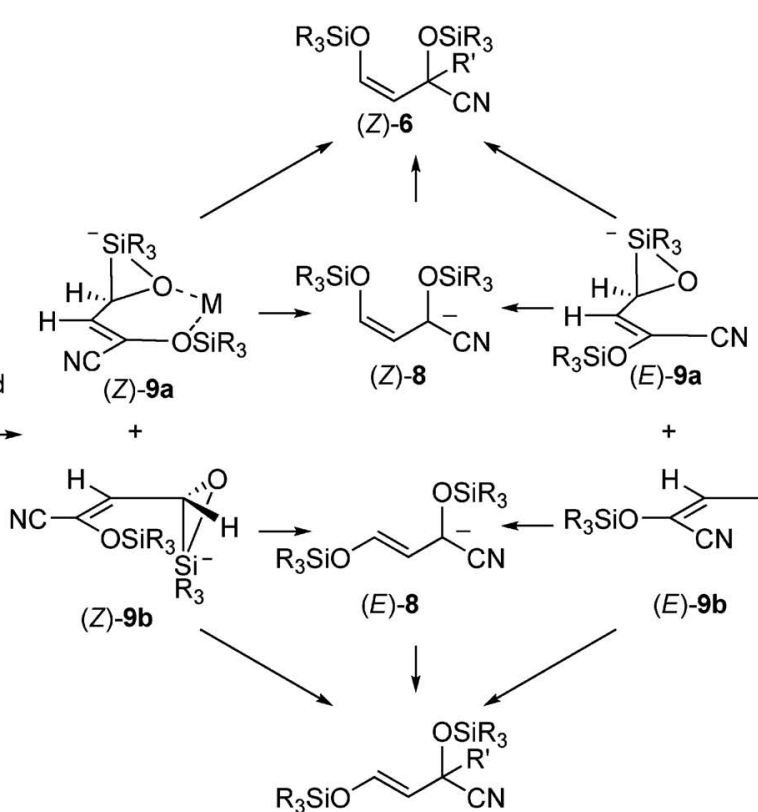

(E)-6

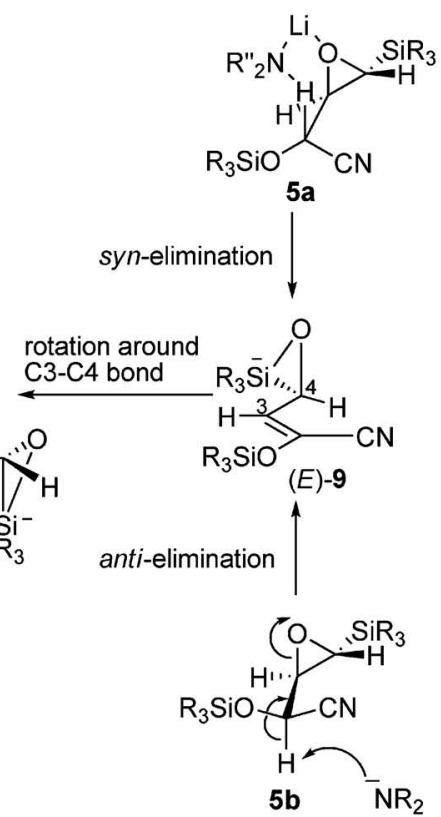

Scheme 3 . 
阻害することによって六員環遷移状態を不利にする HMPA（4.0 当量）を加えて反応を行ったが，回収 した 5 の比は 5a：5b=1.00:0.76であり， HMPA を加えない場合と比較して大きな変化はみられなか った。この結果はキレーション構造を取る syn 脱離 では説明できない。

エポキシドの塩基による開環は一般に syn 脱離で 進行するとされているのに対し, ${ }^{17,18)}$ エポキシシラ ンの場合に anti 脱離で進行するのは, 脱プロトン 化からエポキシドの開環を経て O-Si 結合の形成ま でが連続的に起こっており，六員環遷移状態を取る ことができないためではないかと考えた，そこで， 電子的，立体的に異なるシリル置換基を有する $5 \mathbf{b}$ と 10b の間で競合実験を行うことにした。もし脱 プロトン化／エポキシドの開環が完全に起こったの

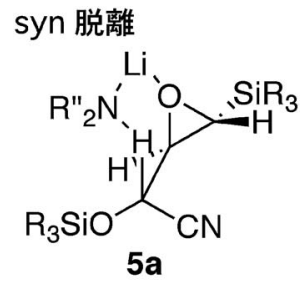

anti 脱離
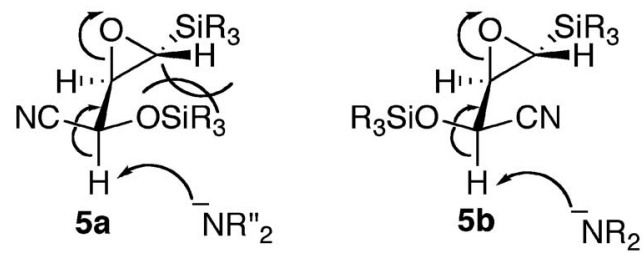

Fig. 2. Mode of Base-induced Ring Opening of Epoxide 5
ちに，O-Si 結合が形成されているのであれば，5b と 10b との間で脱プロトン化の速度に差は生じな いと考えられる。しか，脱プロトン化／エポキシ ドの開環／O-Si 結合の形成が協奏的に進行してい るなら，原料の消失速度が異なるはずである，5b， 10b $1.0: 1.0$ の混合物に 0.7 当量のヨウ化メチル の存在下, 0.7 当量の $\mathrm{LDA}$ を加え, $-80^{\circ} \mathrm{C}$ で 5 分 間反応させたところ，メチル化体が $(E)-6 ：(E)$ -

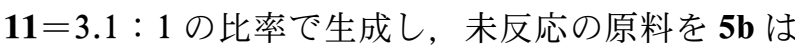
18\%，10bは 40\%の収率で回収した（Table 3）。こ のことから， 5b の方が 10bよりも脱プロトン化が 速いということが明らかになった。

しかし，TBDPS 基がかさ高いため，塩基が近づ く際の立体障害になっている可能性も除外できな い．そこで，塩基のかさ高さを変化させ，同様の反 応を行い，比較することにしたＬLDAより小さな 塩基として lithium diethylamide $\left(\mathrm{LiNEt}_{2}\right)$ ，かさ高 い塩基として lithium 2,2,6,6-tetramethylpiperidide （LTMP）を用いて反応を行ったところ， $\mathrm{LiNEt}_{2}$ で は $(E)-6 ：(E)-\mathbf{1 1}=3.2 ： 1$ であり，LDAを用いた 場合と比較して大きな違いはみられなかった。 LTMP を用いた場合は逆に反応性の差が減少し $(E)-6 ：(E)-11=1.5: 1$ であった．LTMP を用いた 場合に差が小さくなる理由は明らかではないが，少 なくとも塩基がかさ高くなるに従って反応性の差が 増大するという傾向はみられず，エポキシドの $\alpha$ 位のシリル基が塩基が接近する際の立体障害となつ ているという可能性は否定される。したがって，脱 プロトン化/エポキシドの開環と同時に酸素ーケイ

Table 2. Competitive Reaction between $\mathbf{5 a}$ and $\mathbf{5 b}$

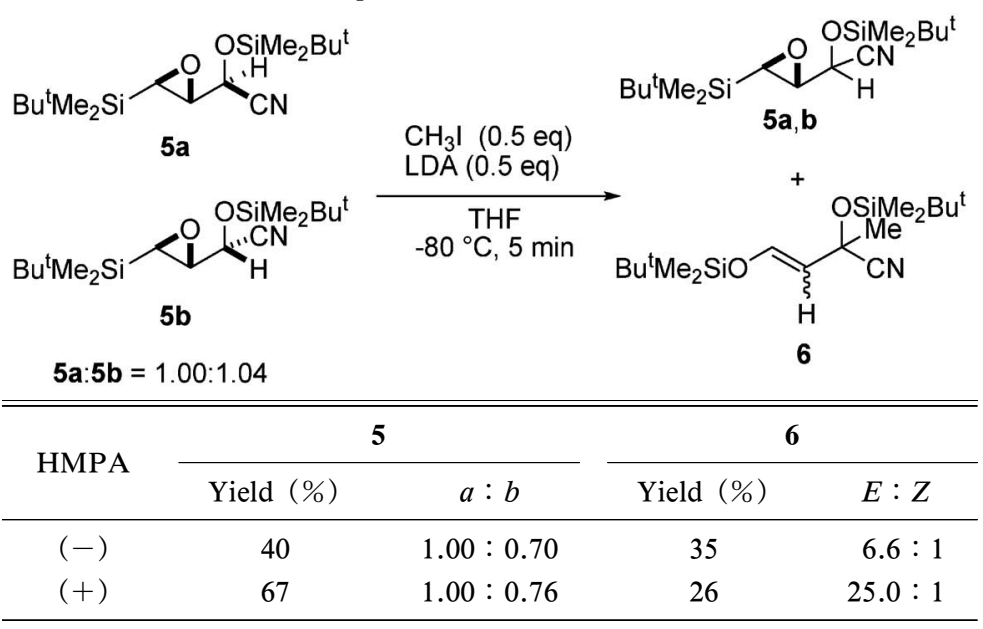


Table 3. Competitive Reaction between $\mathbf{5 b}$ and $\mathbf{1 0 b}$

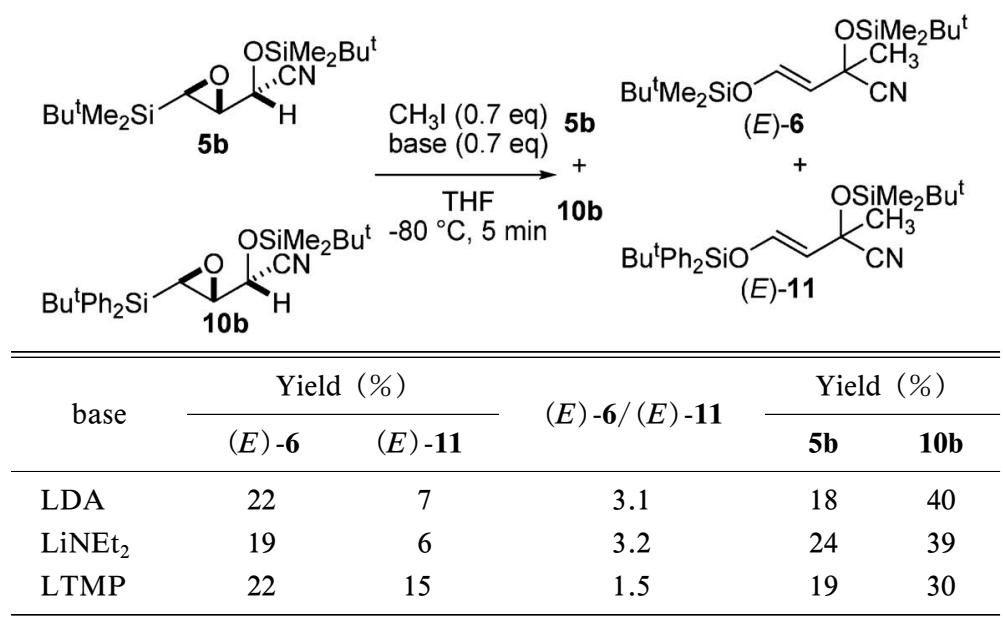

素結合も一部形成されており，この結合はケイ素上 の置換基が立体的に小さい程生成し易いと考えられ る. 以上のことから，エポキシシランの塩基による 開環が anti 型で進行するのは，脱プロトン化と協 奏的に O-Si 結合が形成されるためと結論付けた.

また, $(E)-\mathbf{8}$ と $(Z)-\mathbf{8}$ 間の異性化の有無を調べ る目的で, 別経路で $(E)-\mathbf{8}$ と $(Z)-8$ を発生させる ことにした。も異性化が起これば，本反応におい て 8 を経由せず，シリケート中間体 9 から協奏的に アルキル化が進行していることになる。 $(E, Z)-12$ をそれぞれ塩基で処理し 8 を発生させたのち， 5 分 後にヨウ化メチルを加えたところ，異性化はほとん ど起こっていなかった (Scheme 4)。したがって8 を経由している可能性は除外できない.

以上の実験結果を満たすエポキシシラン転位の反 応機構は次のようになる。 anti 脱離によるエポキシ ドの開環と O-Si 結合の形成が協奏的に起こってシ リケート中間体 $(E, Z)-\mathbf{9 a}, \mathbf{b}$ が形成され，ついで 協奏的にアルキル化される, 若しくはアリルアニオ ン8 経由し, アルキル化される.

\section{4. 不斉転写反応への展開19)}

上記のエポキシシラン転位の反応機構の研究の結 果を踏まえ, シリケート中間体 9 から協奏的かつ立 体特異的にアルキル化が起こっていれば，エポキシ ドのキラリティをカルバニオンに転写することがで きるのではないかと考えた。最初に，光学活性な $\mathbf{5 a}$ を用いて種々の条件下ベンジル化を検討した が，得られた $\mathbf{6}$ は完全にラセミ体だった。この結果 はアルキル化剂との反応が相対的に遅いためと考え

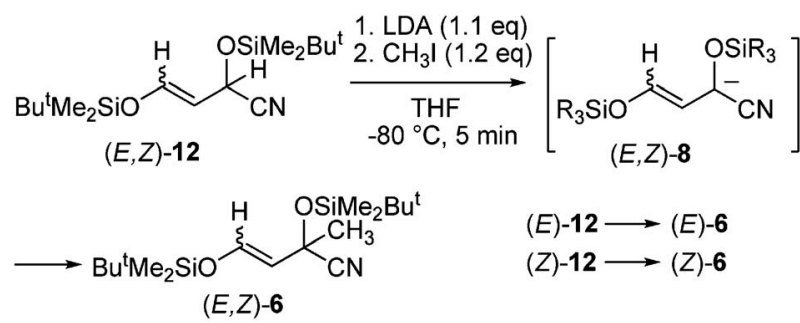

Scheme 4.

られたので，求電子剂との反応を分子内過程とする こととし，発生させたカルバニオンを $[2,3]$-Wittig 転位で捕捉することを検討した。基質として 2-ナ フチル誘導体 13a を用い，[2,3]-Wittig 転位に用い られる最も一般的な溶媒である $\mathrm{THF}$ 中, $-80^{\circ} \mathrm{C}$ 下, n-BuLi で処理したところ，46\%の収率で Wittig 転 位体 14 を与えたが，完全にラセミ化した（Table 4)。しかし，反応を室温で行うと $7 \%$ ee で $\mathbf{1 4}$ が得 られたので, ほかのエーテル系溶媒で検討したとこ ろ，1,4-ジオキサン中，室温で反応させた場合，ほ ぼ定量的エナンチオマー過剩率で転位体が得られる ことが分かった。この結果はエポキシドのキラリテ イを, Brook 転位を利用してカルバニオンに転写で きることを意味しており，新しい不斉誘起の概念を 提供したものと考えている.

ジアステレオマー 13b の場合も同様に進行した が（Table 5)，注目すべき点は，片方のジアスレテ オマーから得られる $E$-体と $Z-$ 体の不斉中心は互い にエナンチオマーの関係にあり，13a から得られる $E-$ 体と 13b から得られる $E-$ 体，13a から得られる 
Table 4. Tandem Epoxysilane Rearrangement/ [2, 3]-Wittig Rearrangement of 13a

\begin{tabular}{|c|c|c|c|c|c|c|c|}
\hline \multirow{2}{*}{ Entry } & \multirow{2}{*}{ Solvent } & \multirow{2}{*}{ Temperature } & \multirow{2}{*}{ Yield (\%) } & \multirow{2}{*}{$\begin{array}{l}\text { Recovered } \\
\operatorname{SM}^{a)}(\%)\end{array}$} & \multirow{2}{*}{$E: Z$} & \multicolumn{2}{|c|}{ ee $(\%)^{b)}$} \\
\hline & & & & & & $E$ & $Z$ \\
\hline 1 & THF & $-80^{\circ}$ to $-75^{\circ} \mathrm{C}$ & 46 & 45 & $5.3: 1$ & 0 & 0 \\
\hline 2 & THF & $-35^{\circ}$ to $-30^{\circ} \mathrm{C}$ & 88 & - & $2.4: 1$ & 0 & 0 \\
\hline 3 & THF & $25^{\circ}$ to $30^{\circ} \mathrm{C}$ & 80 & - & $1.2: 1$ & 7 & 0 \\
\hline 4 & $\mathrm{Et}_{2} \mathrm{O}$ & $-80^{\circ}$ to $-75^{\circ} \mathrm{C}$ & 0 & 94 & - & - & - \\
\hline 5 & $\mathrm{Et}_{2} \mathrm{O}$ & $-35^{\circ}$ to $-30^{\circ} \mathrm{C}$ & 45 & 35 & $1: 9.5$ & 81 & 74 \\
\hline 6 & $\mathrm{Et}_{2} \mathrm{O}$ & $25^{\circ}$ to $30^{\circ} \mathrm{C}$ & 72 & - & $1: 6.8$ & 84 & 80 \\
\hline 7 & 1, 4-dioxane & $25^{\circ}$ to $30^{\circ} \mathrm{C}$ & 85 & - & $1: 2.6$ & 96 & 74 \\
\hline 8 & 1, 4-dioxane & $50^{\circ}$ to $60^{\circ} \mathrm{C}$ & 82 & - & $1: 2.6$ & 91 & 82 \\
\hline
\end{tabular}

a) $\mathrm{SM}=$ starting material. $b$ ) Corrected for ee of the starting material ( $90 \%$ ee).

Table 5. Tandem Epoxysilane Rearrangement/ [2, 3]-Wittig Rearrangement of 13b

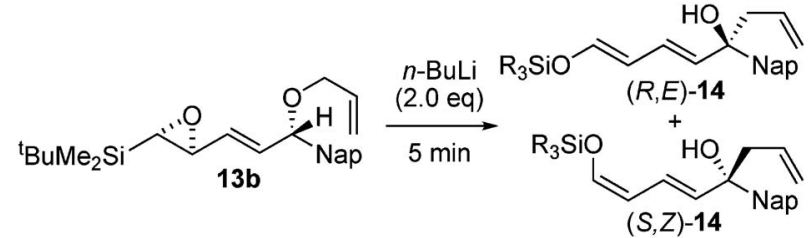

\begin{tabular}{cccccccc}
\hline \hline Entry & Solvent & Temperature & Yield (\%) & $\begin{array}{c}\text { Recovered } \\
\text { SM }^{a)}(\%)\end{array}$ & $E: Z$ & $\begin{array}{c}\text { ee }(\%)^{b)} \\
E\end{array}$ \\
\hline 1 & $\mathrm{THF}$ & $-80^{\circ}$ to $-75^{\circ} \mathrm{C}$ & 54 & 36 & $E$ & 0 & - \\
2 & $\mathrm{THF}$ & $-35^{\circ}$ to $-30^{\circ} \mathrm{C}$ & 91 & - & $E$ & 0 & - \\
3 & $\mathrm{THF}$ & $25^{\circ}$ to $30^{\circ} \mathrm{C}$ & 90 & - & $15.4: 1$ & 5 & 0 \\
4 & $\mathrm{Et} \mathrm{H}_{2} \mathrm{O}$ & $-80^{\circ}$ to $-75^{\circ} \mathrm{C}$ & 0 & 84 & - & - & - \\
5 & $\mathrm{Et}_{2} \mathrm{O}$ & $-35^{\circ}$ to $-30^{\circ} \mathrm{C}$ & 51 & 41 & $12.0: 1$ & 90 & 36 \\
6 & $\mathrm{Et}_{2} \mathrm{O}$ & $25^{\circ}$ to $30^{\circ} \mathrm{C}$ & 71 & - & $2.6: 1$ & 91 & 58 \\
7 & $1,4-$ dioxane & $25^{\circ}$ to $30^{\circ} \mathrm{C}$ & 92 & - & $8.1: 1$ & 97 & 45 \\
8 & $1,4-$ dioxane & $50^{\circ}$ to $60^{\circ} \mathrm{C}$ & 81 & - & $5.3: 1$ & 96 & 49 \\
\hline
\end{tabular}

a) $\mathrm{SM}=$ starting material. $b$ ) Corrected for ee of the starting material (91\% ee).

$Z$-体と 13b から得られる $Z$-体もそれぞれエナンチ オマーの関係にあるという結果である. 本反応の詳 細な反応機構について現在検討中である.

\section{5. エポキシシラン転位の合成反応としての展開}

エポキシシランの隣接位にカルバニオンを発生さ せることにより Brook 転位を経由して $\beta$-シロキシ アリルアニオンが生成するというエポキシシラン転 位は，その他にも種々の合成反応に展開可能である.

5-1. アクロレイン $\beta$-アニオン等価体としてのエ ポキシシラン20) $\quad \alpha, \beta$-不飽和アルデヒドの合成法
としては Wittig タイプの反応が汎用されている が，この場合，原料がケトンあるいはアルデヒドに 限定される。一方，アクロレイン $\beta$-アニオン等価 体を用いてハロアルカンなどから合成する方法もい くつか報告されているが, ${ }^{21)}$ その多くはアルデヒド 基を再生する条件が過酷であるため，共存可能な官 能基が限定されている，われわれは，脱離可能な $p$-トルエンスルホニル基を有する 15 が緩和な条件 下，アクロレイン $\beta$-アニオン等価体として機能す ることを見い出した．15 をアルキル化剂の存在下 
$-80^{\circ} \mathrm{C}$ において NaHMDS で処理し昇温後 $n-\mathrm{Bu}_{4} \mathrm{NF}$ 及びエタノールを加えたところ，ワンポットで対応 する共役アルデヒド 16a-e を得ることができた (Table 6)。興味深いことに，シロキシ基やエステ ル基などを有するハロゲン化アルキルを用いても収 率よく反応が進行した。 エタノールの添加は $n-\mathrm{Bu}_{4} \mathrm{NF}$ の低温での溶解性の向上と副反応を誘起する $p$ $\mathrm{TolSO}_{2}^{-}$の求核性の低下を意図したもので，添加し ないと収率の大幅な低下を招いた。また，八ロゲン 化アルキルの代わりにアルデヒドを用いても問題な く進行し， $\gamma$-ヒドロキシ- $\alpha, \beta$-不飽和アルデヒドが 得られた。 また， 15 はプロパルギルアルコールか ら容易に（カラムクロマトグラフィーによる精製な しに）合成可能でかつ室温で長期間保存可能な結晶 性化合物であることから，アクロレイン $\beta$ アニオ ン等価体試薬として合成反応への応用が期待される.

5-2. Wittig 試薬等価体としてのエポキシシラ ン22) 次に，ホスホニオ基を導入した基質を塩基 で処理し，アルデヒドあるいはケトンと反応させれ ば，Wittig タイプの反応によりジエノールシリル エーテルを一挙に合成できるのではないかとの着想 を持った。 Wittig 試薬 $\mathbf{1 7}(\mathrm{X}=\mathrm{Cl}, \mathrm{Br}, \mathrm{I})$ の単離精 製は困難であったが，トリフルオロメタンスルホ ネート誘導体 $17 （ \mathrm{X}=\mathrm{OTf} ）$ が結晶として単離可能 で，室温でも安定に保存できることを見い出した. 17 の反応は塩基として $n$-BuLi を用いることで円滑 に進行し，対応するジエノールシリルエーテル 18
を与えた（Table 7).

5-3. エノエートへの共役付加によるアニオン発 生によるエポキシシラン転位23)エポキシシラン の $\alpha$ 位にアニオンを発生させる方法として，脱プ ロトン化以外に， $\alpha$ 位にエポキシシラン部を有する エノエート誘導体に対する求核剤の共役付加を用い ることができ，またこのとき，求核牏としてエノ レートのような分子内求核・求電子剂を用いれば, 高度に官能基化された環状化合物が得られるのでは ないかと考えた。種々の求核・求電子剂を検討した 結果， $\alpha$ クロロアミドの Liエノレートを用いた場 合最もよい結果が得られ，好収率かつシス選択的に 多官能性シクロプロパン誘導体 $\mathbf{2 0 a}-\mathbf{e}$ が得られた (Table 8).

\section{6. おわりに}

以上のようにわれわれは，ケイ素の特性を利用し た新しい反応であるエポキシシラン転位を発見し， その詳細な反応機構を解明した。 さらに，光学活性 なエポキシドを用いてその不斉をカルバニオンに転 写するという，新しいタイプの不斉反応を開発し， 種々の基質を用いて合成化学的に有用な反応へと展 開した。今後さらに詳細な不斉転写機構の解明など について検討していきたいと考えている.

謝辞本研究は, 広島大学大学院医歯薬学総合 研究科創薬合成化学研究室で行われたものであり, 終始暖かい御指導を賜りました武田 敬教授に深く

Table 6. One-pot Synthesis of $\mathbf{1 6}$

1. $R X(1.0 \mathrm{eq})$

NaHMDS (1.0 eq)

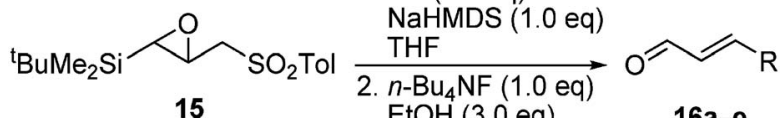

15 $\mathrm{EtOH}(3.0 \mathrm{eq})$

16a-e

\begin{tabular}{llcc}
\hline \hline \multicolumn{1}{c}{$\mathrm{RX}$} & \multicolumn{2}{c}{ Conditions } & Yield (\%) \\
\hline $\mathrm{BrCH}_{2} \mathrm{Ph}$ & 1. & $-80^{\circ}$ to $-60^{\circ} \mathrm{C}, 30 \mathrm{~min}$ & 85 \\
& 2. & $-80^{\circ}$ to $-70^{\circ} \mathrm{C}, 15 \mathrm{~min}$ & \\
$\mathrm{ICH}_{2}\left(\mathrm{CH}_{2}\right)_{6} \mathrm{CH}_{3}$ & 1. & $-80^{\circ}$ to $-50^{\circ} \mathrm{C}, 40 \mathrm{~min}$ & 84 \\
& 2. & $-80^{\circ}$ to $-70^{\circ} \mathrm{C}, 20 \mathrm{~min}$ & \\
$\mathrm{BrCH}_{2} \mathrm{CH}=\mathrm{CH}\left(\mathrm{CH}_{2}\right)_{4} \mathrm{CH}_{3}$ & 1. & $-80^{\circ}$ to $-50^{\circ} \mathrm{C}, 30 \mathrm{~min}$ & 82 \\
& 2. & $-80^{\circ}$ to $-70^{\circ} \mathrm{C}, 15 \mathrm{~min}$ & \\
$\mathrm{ICH}_{2} \mathrm{CH}_{2} \mathrm{CH}_{2} \mathrm{CH}_{2} \mathrm{OSiMe} \mathrm{Bu}^{\mathrm{t}}$ & 1. & $-80^{\circ}$ to $-40^{\circ} \mathrm{C}, 45 \mathrm{~min}$ & 68 \\
& 2. & $-80^{\circ}$ to $-70^{\circ} \mathrm{C}, 15 \mathrm{~min}$ & \\
$\mathrm{ICH}_{2} \mathrm{CH}_{2} \mathrm{CH}_{2} \mathrm{CO}_{2} \mathrm{Et}$ & 1. & $-80^{\circ} \mathrm{C} 5 \mathrm{~min} ;$ then $\mathrm{RX}$ & 74 \\
& & $-80^{\circ}$ to $-40^{\circ} \mathrm{C}, 45 \mathrm{~min}$ & \\
& 2. & $-80^{\circ}$ to $-70^{\circ} \mathrm{C}, 20 \mathrm{~min}$ & \\
\hline
\end{tabular}


Table 7. Reaction of $\mathbf{1 7}$ with Aldehyde

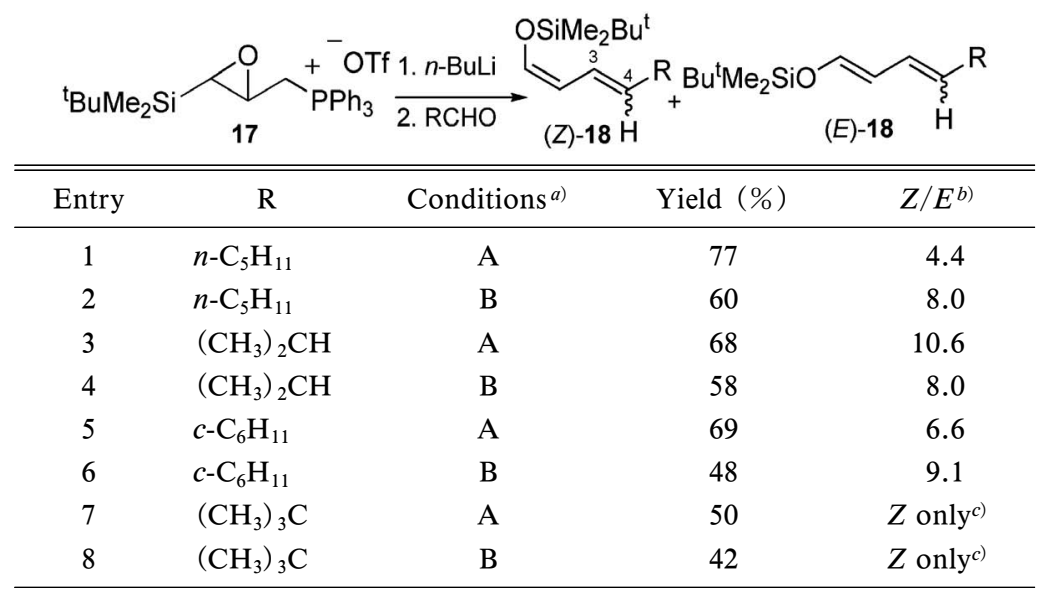

a) condition $\mathrm{A}: 1.15^{\circ}$ to $20^{\circ} \mathrm{C}, 3 \mathrm{~min}, 2.15^{\circ}$ to $20^{\circ} \mathrm{C}, 5 \mathrm{~min}$ in $\mathrm{THF}$, condition $\mathrm{B}: 1 .-40^{\circ}$ to

$-35^{\circ} \mathrm{C}, 3 \mathrm{~min}, 2 .-40^{\circ}$ to $-30^{\circ} \mathrm{C}, 25 \mathrm{~min}$ in $\mathrm{CH}_{2} \mathrm{Cl}_{2}$. b) The ratios of $3 E / 3 Z$ were almost 1.0 .

c) $3 Z$ isomer was formed exclusively.

Tabla 8. Reaction of $\mathbf{1 9}$ with the Lithium Enolate of $N, N$ Diethylchloroacetamide

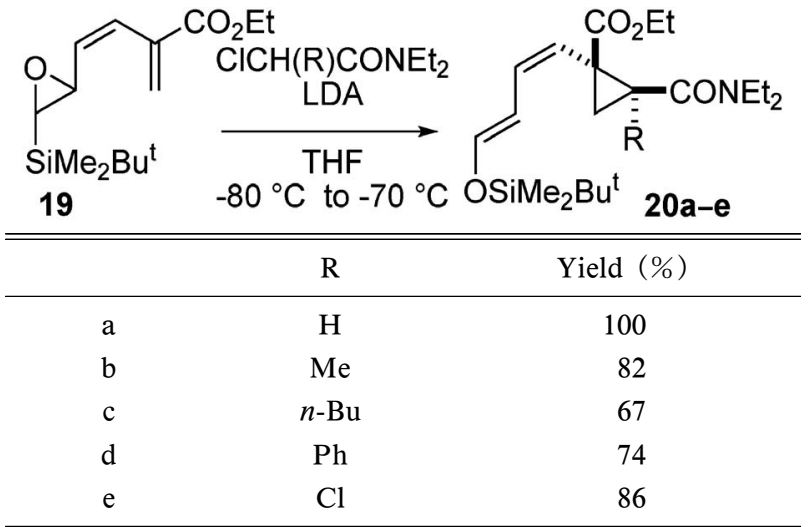

感謝致します。また，共同研究者の学生諸氏，X 線結晶構造解析を行って頂いた徳島文理大学香川薬 学部の山口健太郎教授, 桝飛雄真博士，川幡正俊博 士，質量分析，元素分析を行って頂いた広島大学自 然科学研究支援開発センター（N-BARD）に感謝 いたします。なお，本研究の一部は財日本科学協会 (笹川科学研究助成) による助成によりなされたも のであり，感謝致します。

\section{REFERENCES}

1) Katsuki T., Martin V. S., Org. React., 48, 1299 (1996).

2) Tu Y., Wang Z.-X., Shi Y., J. Am. Chem. Soc., 118, 9806-9807 (1996).

3) Takeda K., Kawanishi E., Sasaki S., Taka- hashi Y., Yamaguchi K., Org. Lett., 4, 15111514 (2002).

4) Brook M. A., "Silicon in Organic, Organometallic, and Polymer Chemistry," John Wiley \& Sons, Inc. 2000.

5) Brook A. G., Bassindale A. R., "Rearrangements in Ground and Excited States," ed. by de Mayo P., Academic Press, New York, 1980, pp 149-221.

6) Brook A. G., Acc. Chem. Res., 7, 77-84 (1974).

7) Moser W. H., Tetrahedron, 57, 2065-2084 (2001).

8) Ricci A., Degl'Innocenti A., Synthesis, 647660 (1989).

9) Page P. C. B., Klair S. S., Rosenthal S., Chem. Soc. Rev., 19, 147-195 (1990).

10) Qi H., Curran D. P., "Comprehensive Organic Functional Group Transformations," eds. by Katritzky A. R., Meth-Cohn O., Rees C. W., Moody C. J., Pergamon, Oxford, 1995, pp 409-431.

11) Cirillo P. F., Panek J. S., Org. Prep. Proc. Int., 24, 553-582 (1992).

12) Patrocinio A. F., Moran P. J. S., J. Braz. Chem. Soc., 12, 7-31 (2001).

13) Takeda K., J. Synth. Org. Chem., Jpn., 55, 774-784 (1997).

14) Takeda K., Yakugaku Zasshi, 117, 368-377 (1997).

15） Sasaki M., Takeda K., J. Synth. Org. Chem., 
Jpn., 64, 1148-1158 (2006).

16) Sasaki M., Kawanishi E., Nakai Y., Matsumoto T., Yamaguchi K., Takeda K., J. Org. Chem., 68, 9330-9339 (2003) .

17) Crandall J. K., Apparu N., Org. React., 29, 345-443 (1983).

18) Fleming F. F., Wang Q. Z., Steward O. W., J. Org. Chem., 66, 2171-2174 (2001).

19) Sasaki M., Higashi M., Masu H., Yamaguchi K., Takeda K., Org. Lett., 7, 5913-5915
(2005).

20) Sasaki M., Takeda K., Org. Lett., 6, 48494851 (2004).

21) Chinchilla R., Najera C., Chem. Rev., 100, 1891-1928 (2000).

22) Sasaki M., Horai M., Takeda K., Tetrahedron Lett., 47, 9271-9273 (2006).

23) Okamoto N., Sasaki M., Kawahata M., Yamaguchi K., Takeda K., Org. Lett., 8, 18891891 (2006). 